\title{
Bacteriophages with Potential for Inactivation of Fish Pathogenic Bacteria: Survival, Host Specificity and Effect on Bacterial Community Structure
}

\author{
Carla Pereira, Yolanda J. Silva, Ana L. Santos, Ângela Cunha, Newton C. M. Gomes and \\ Adelaide Almeida *
}

CESAM and Department of Biology, Campus of Santiago, University of Aveiro, 3810-193 Aveiro, Portugal; E-Mails: csgp@ua.pt (C.P.); yolanda@ua.pt (Y.J.S.); alsantos@ua.pt (A.L.S.); acunha@ua.pt (Â.C.); gomesncm@ua.pt (N.C.M.G.)

* Author to whom correspondence should be addressed; E-Mail: aalmeida@ua.pt; Tel.: +351-234-370-200; Fax: +35-234-372-587.

Received: 22 September 2011; in revised form: 21 October 2011 / Accepted: 28 October 2011 / Published: 7 November 2011

\begin{abstract}
Phage therapy may represent a viable alternative to antibiotics to inactivate fish pathogenic bacteria. Its use, however, requires the awareness of novel kinetics phenomena not applied to conventional drug treatments. The main objective of this work was to isolate bacteriophages with potential to inactivate fish pathogenic bacteria, without major effects on the structure of natural bacterial communities of aquaculture waters. The survival was determined in marine water, through quantification by the soft agar overlay technique. The host specificity was evaluated by cross infection. The ecological impact of phage addition on the structure of the bacterial community was evaluated by DGGE of PCR amplified 16S rRNA gene fragments. The survival period varied between 12 and 91 days, with a higher viability for Aeromonas salmonicida phages. The phages of Vibrio parahaemolyticus and of A. salmonicida infected bacteria of different families with a high efficacy of plating. The specific phages of pathogenic bacteria had no detectable impact on the structure of the bacterial community. In conclusion, $V$. parahaemolyticus and $A$. salmonicida phages show good survival time in marine water, have only a moderated impact on the overall bacterial community structure and the desired specificity for host pathogenic bacteria, being potential candidates for therapy of fish infectious diseases in marine aquaculture systems.
\end{abstract}

Keywords: phage therapy; bacteriophages; fish pathogenic bacteria; aquaculture; bacterial community structure 


\section{Introduction}

Nearly one-third of the world's seafood supplies come from aquaculture industry, representing the fastest growing agricultural sector. Over the past ten years, aquaculture production has increased on average by $6 \%$ per year [1]. The production has increased from 8.7 million tons of fish in 1990 to 31.6 million tons in 2006 [1,2]. Fish farming plants, however, often suffer from heavy financial losses [3-5] due to the development of infections caused by microbial pathogens, including multidrug resistant bacteria that are easily transmitted through water and therefore able to infect a great variety of fish species.

Although pathogenic species have been described in the majority of the existing taxonomic groups, only a relatively small number is responsible for important economic losses in cultured fish worldwide [6]. Vibriosis and photobacteriosis are primarily diseases of marine and estuarine fish, both in natural and commercial production systems throughout the world, occurring only occasionally in freshwater fish. Both diseases can cause significant mortality in fish, reaching values of up to $100 \%$ in infected facilities, being currently responsible for most outbreaks in fish farming plants. Vibriosis and photobacteriosis are caused by bacteria from the family Vibrionaceae. Vibriosis is caused by species of Vibrio, namely by Vibrio anguillarum [7-9]. Others species of Vibrio, such as $V$. alginolitycus, $V$. anguillarum, V. carchariae, $V$. salmonicida, $V$. damsela, $V$. ordalii, $V$. parahemolyticus and $V$. vulnificus, causes also important infections in several species of fish [10,11]. Photobacteriosis is caused by Photobacterium damselae subsp. piscicida (formerly Pasteurella piscicida) which is a highly pathogenic bacterium that does not seem to have host specificity, infecting a diverse range of fish species [6,12]. Other bacteria as A. salmonicida, causative agent of furunculosis, Rickettsia-like bacteria, Cytophaga marina, Flavobacterium psychrophilum and Pseudomonas plecoglossicida are also important groups of fish pathogens, affecting a variety of fish species from diverse geographical aquatic environments $[13,14]$.

Although vaccination is the ideal method to prevent infectious diseases [15-18], many different kinds of infectious diseases occur locally in a variety of fish species [19], thus limiting its application. On the other hand, chemotherapy is a rapid and effective method to treat or prevent bacterial infections, but the frequent use of antibiotics has resulted in an increasing frequency of drug-resistant pathogenic bacteria in the aquaculture, agriculture, and medical realms. This problem can be particularly serious since few chemotherapeutic drugs are licensed for fisheries use [19-21].

To reduce the risk of development and spreading of antibiotic resistant bacteria, other more environmentally friendly methods to control fish disease in aquaculture must be developed. In line with this idea, the use of phage therapy in aquaculture seems to be very promising, as bacterial diseases are a major problem in the expanding aquaculture industry [22-24].

Bacteriophages (commonly phages) are bacterial viruses extremely abundant in nature and believed to be important in controlling bacterial populations in natural systems [25], even being multidrug resistant [26-28]. The use of phages to control infections in aquatic environment, such as fish diseases, seems to be particularly promising $[19,29,30]$. As the host fish organisms live in aqueous media, the therapeutic phages can have continuous and close physiological contact with the pathogens in a natural arrangement. In fact, the potential use of phage therapy to control disease in aquaculture systems has been demonstrated in some studies [19,31-34]. Isolated phages with lytic activity against 
Vibrio harveyi were applied as phage therapy against luminous vibriosis to improve the survival of Penaeus monodon larvae [34]. The interaction between A. salmonicida and a bacteriophage, to treat furunculosis in brook trout, showed that bacteriophage combination could be successfully used in preventive programs in fish farms [31]. This study showed that more than one phage could infect A. salmonicida and that mutants resistant to one phage were sensitive to one or more phages. More than $25 \%$ of the mutants seemed to revert to the original strain phenotype after the first plating. All mutants were sensitive to three or more phages [31].

The success of phage therapy to control pathogenic bacteria of fish depends on viral survival and viability in culture water of fish-farming plants. However, although there are some data available on the mechanisms and rates of mortality or loss of infectivity of phages in marine waters, little is known about their time of survival in the marine environment. Solar radiation has been recognized as the most important factor in the loss of phage infectivity in surface coastal water. Suttle and coworkers have examined several processes implicated in the loss of infectivity of viruses in seawater. They used various indigenous marine bacteriophages [35,36], cyanophage [35] and a virus of Micromonas pusilla, a cosmopolitan marine phytoplankton [37] and concluded that sunlight was the dominant factor controlling decay of viral infectivity in seawater. De Paepe and Taddei [38] by comparing life history traits of 16 phages infecting the bacterium Escherichia coli, showed that their mortality rate is constant with time and negatively correlated to their multiplication rate in the bacterial host. The authors showed that the capsid thickness and the density of the packaged genome account for $82 \%$ of the variation in the mortality rate [38].

The success of phage therapy also depends on the effect of phages on the bacterial community, namely when semi-intensive regimes are used. In semi-intensive aquaculture systems, non-pathogenic bacteria have a central role in the functioning and productivity of these ecosystems. Bacteria are the most important biological component involved in the turnover of organic matter in aquatic systems $[39,40]$. Although the host specificity of many phages is likely to restrict their impact on the diverse members of a microbial assemblage, phage therapy would require adding massive quantities of phages to water. Therefore, a careful evaluation on the impact of any phage on the bacterial community structure should be conducted prior to implementation of phage therapy. Previous studies have demonstrated a huge diversity of both phages and hosts within a single phage-host system suggesting that phages drive the diversification of bacterial populations within a given phylotype [41]. As the vast majority of prokaryotic taxa are not cultivable, culture-independent methods such as DGGE must be used to evaluate the effect of phage therapy on the total bacterial community structure.

The main goal of this work was to determine the survival of $A$. salmonicida and $V$. parahaemolyticus phages in marine water and to study their impact on the structure of the bacterial community of an aquaculture system of the Ria de Aveiro (Portugal). 


\section{Results and Discussion}

\subsection{Results}

\subsubsection{Water Properties}

In the aquaculture system, salinity varied between 31.0 PSU in March 2009 and 33.8 PSU in September 2009. Temperature varied from $13.8^{\circ} \mathrm{C}$ in March 2009 to $20.2{ }^{\circ} \mathrm{C}$ in August 2009 and the dissolved oxygen ranged between $2.7 \mathrm{mg} \cdot \mathrm{L}^{-1}$ in May 2009 and $1.7 \mathrm{mg} \cdot \mathrm{L}^{-1}$ in July 2009.

\subsubsection{Phages Isolation and Classification}

Two phages were isolated from samples of aquaculture water: A. salmonicida phages (AS-1) and $V$. parahemolyticus phages (VP-1).

The presence of phages was conclusively confirmed by TEM examination of concentrated phage filtrates (Figure 1) [42]. Phage VP-1 and AS-1 appeared morphologically similar, exhibiting a tailed phage with an icosahedral head of approx. 50 and $40 \mathrm{~nm}$ diameter, respectively. Both isolated phages displayed binary symmetry and a long tail, approx. $100 \mathrm{~nm}$ in length. Phage isolates formed small plaques with a diameter varying between $1.5 \mathrm{~mm}$ and $2.0 \mathrm{~mm}$ after $6-8 \mathrm{~h}$ of incubation at $25^{\circ} \mathrm{C}$.

Figure 1. Phage plaques and electron micrographs of the phages. (A) VP-1 $($ scale bars $=50 \mathrm{~nm})$; and $(\mathbf{B})$ AS-1 $($ scale bars $=20 \mathrm{~nm})$.
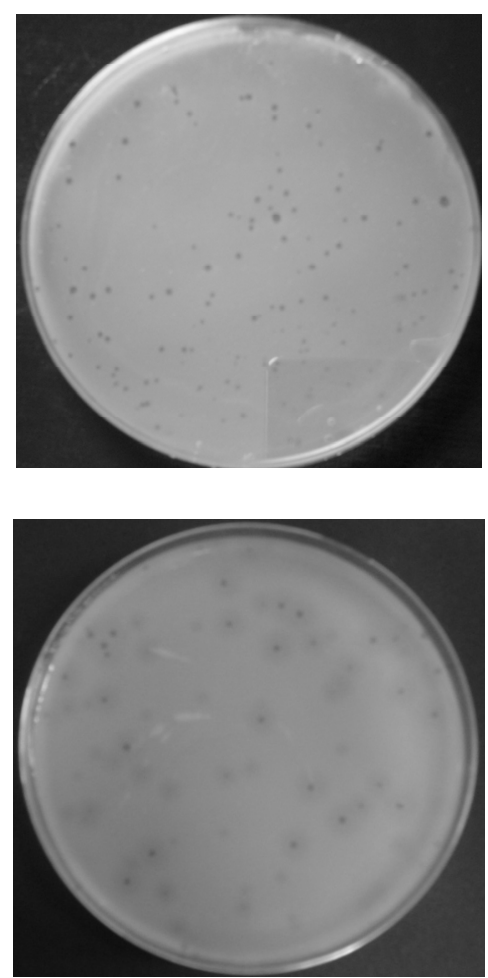

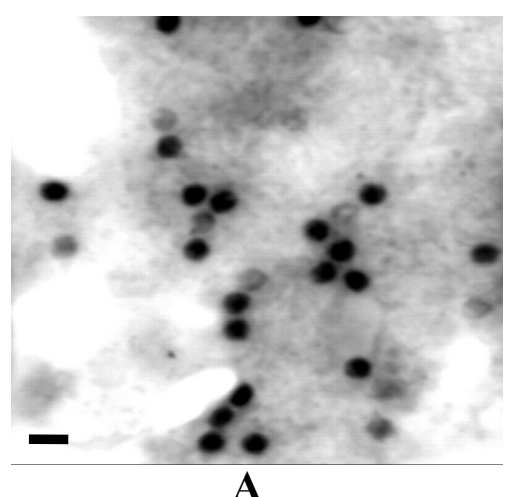

A

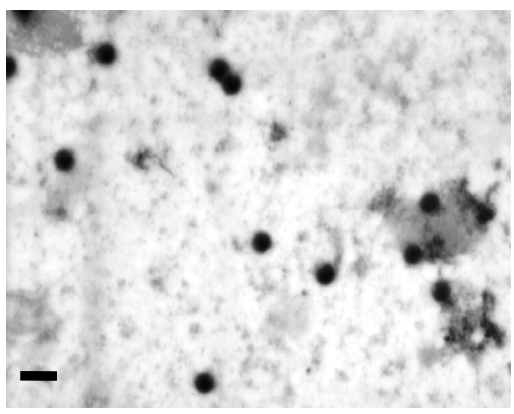

B
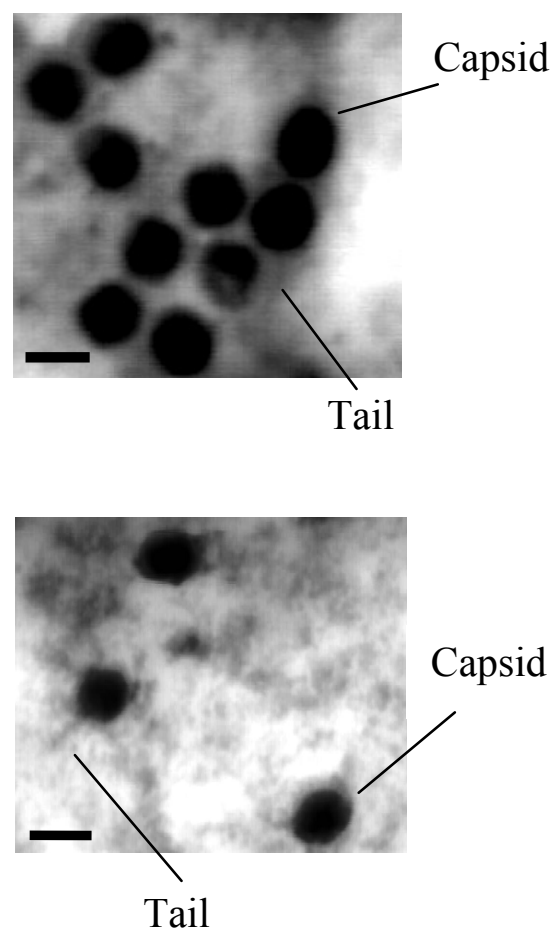

The analysis of the nucleic acids of phages was conducted by three different methods: Strand Displacement Amplification (SDA) kit, enzyme digestion (DNase I, RNase I) and digestion with restriction enzymes (PstI and BamI). The nucleic acids of AS-1 and VP-1 were amplified by the SDA kit, as well as, digested by DNase I but not by RNase I, indicating that DNA is the nucleic acid. The 
nucleic acid of VP-1 was digested with PstI and BamI (Figure 2) in contrast with AS-1 that, after many attempts, was not cleaved by these enzymes. Nucleic acid analysis suggested that these phages have double stranded DNA genome.

Figure 2. Phage VP-1 DNA following digestion with Pst I and BamI. Lanes: M, Marker-DNA and DNA of bacteriophage fX174 digest with Hind III and Hae III (Finnzymes); 1, VP-1 DNA digested with Bam I and PstI.

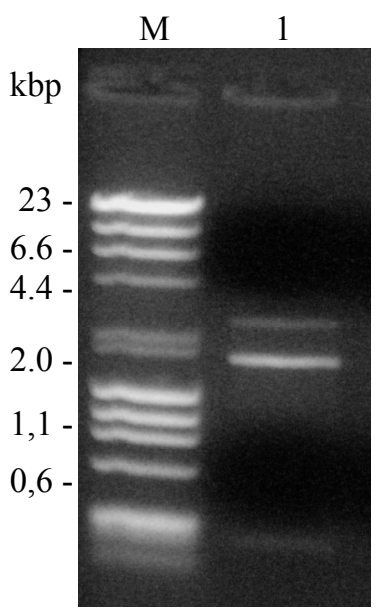

\subsubsection{Phage Host Range Analysis}

The phage VP-1 infected Vibrio anguillarum and Aeromonas salmonicida presenting an efficacy of 83.27 and 64.75, respectively (Table 1). The phage AS-1 infected $V$. anguillarum and $V$. parahemolyticus presenting an efficacy of 98.87 and $96.03 \%$, respectively (Table 1). None of the nine phages was effective against Photobacterium damselae subsp. damselae, Photobacterium damselae subsp. piscicida, Vibrio fischeri, Escherichia coli, Pseudomonas aeruginosa, Pseudomonas fluorescens, Pseudomonas putida, Pseudomonas gingeri and Pseudomonas segetis.

Table 1. Efficacy of plating (\%) to different fish pathogenic bacteria.

\begin{tabular}{ccc}
\hline FISH PATHOGENIC & \multicolumn{2}{c}{ PHAGES } \\
\cline { 2 - 3 } BACTERIA & AS-1 & VP-1 \\
\hline V. anguillarium & 98.87 & 83.27 \\
V. parahaemolyticus & 96.03 & 100 \\
V. fischeri & 0 & 0 \\
A. salmonicida & 100 & 64.75 \\
P. damselae subsp. damselae & 0 & 0 \\
P. damselae subsp. piscicida & 0 & 0 \\
E. coli & 0 & 0 \\
P. aeruginosa & 0 & 0 \\
P. fluorescens & 0 & 0 \\
P. putida & 0 & 0 \\
P. segetis & 0 & 0 \\
P. gingeri & 0 & 0 \\
\hline
\end{tabular}




\subsubsection{Determination of Phage Survival}

The pattern of phage survival in aquaculture water was different for the two phages tested. The abundance of AS-1 phage decreased by one order of magnitude in the first 15 days and, after reaching a plateau, that value remained constant during 45 days. Afterwards, the phage titer decreased slightly until 91 days (Figure 3). In contrast, the abundance of VP-1 phage decreased strongly during the incubation period, showing a survival period of 16 days, much lower than the AS-1 phage (Figure 3).

Figure 3. Survival of AS-1 and VP-1 phages. The values are expressed as the average of three independent experiments. Error bars represent the standard deviation. ( AS-1 phage,

$\Delta$ VP-1 phage).

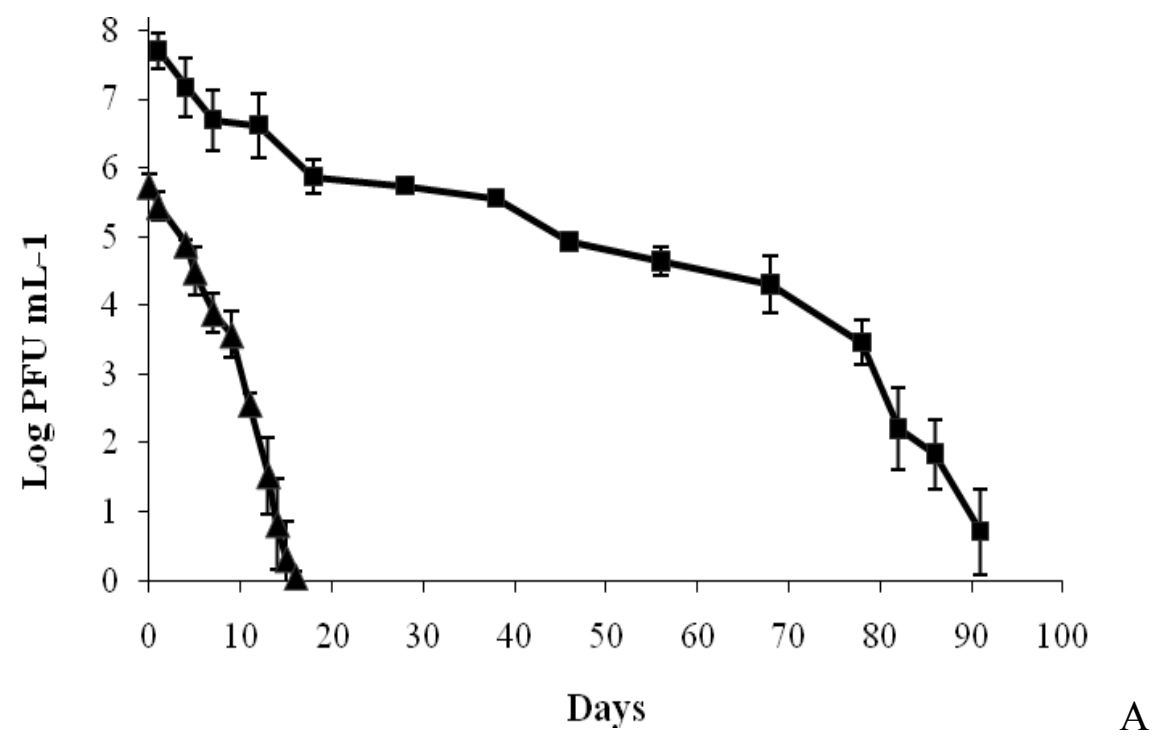

\subsubsection{Effects of the Phages on the Bacterial Community Structure}

The effect of the addition of AS-1 and VP-1 phage on the structural diversity of the bacterial community of the aquaculture water as described by $16 \mathrm{~S}$ rDNA DGGE profiles can be observed in Figures 4 and 5. The addition of the phages did not significantly alter the bacterial ribotype diversity. The pattern of bands in the sample with added phages (P-100) was similar to that of the control incubated during $10 \mathrm{~h}$ without phages $\left(\mathrm{W}-\mathrm{T}_{10}\right)$. The major difference was observed for the incubated controls with chloroform (TSB-CL) for A. salmonicida samples and for the non-incubated controls (W- $\mathrm{T}_{0}$ ) for $V$. parahaemolyticus samples (Figures 4 and 5). 
Figure 4. DGGE profile of PCR-amplified 16S rRNA gene fragments after AS-1 (A) and VP-1 (B) phages addition to bacterial community of the aquaculture system. $\mathrm{M}$ - molecular weight marker, $\mathrm{W}-\mathrm{T}_{0}$ - water samples at time zero; $\mathrm{W}-\mathrm{T}_{10}$ - water samples incubated during $10 \mathrm{~h}$ without phages; P-100 — water samples added of $100 \mu \mathrm{L}$ of AS-1 (A) and VP-1 (B) phages incubated during $10 \mathrm{~h}$; TSB-CL-water samples incubated during $10 \mathrm{~h}$ with TSB and $1 \%$ of chloroform without phages.

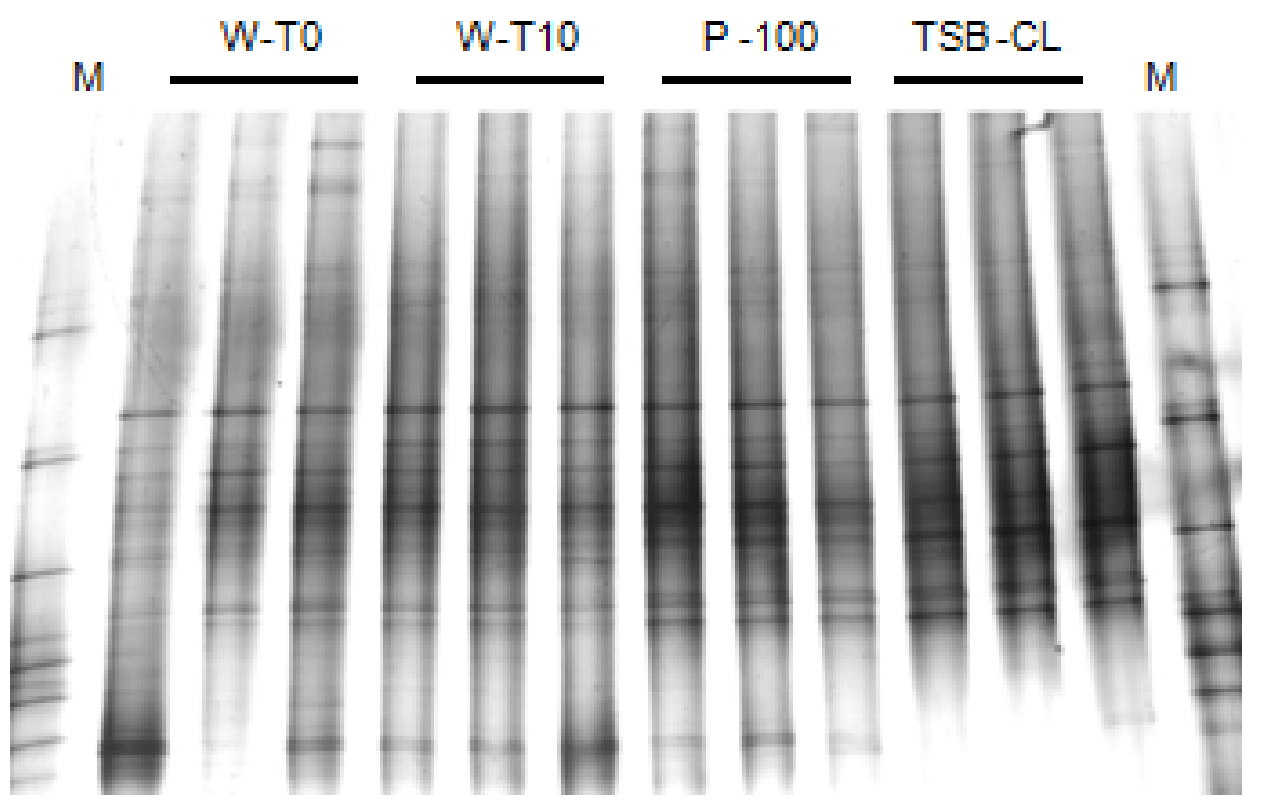

(A)

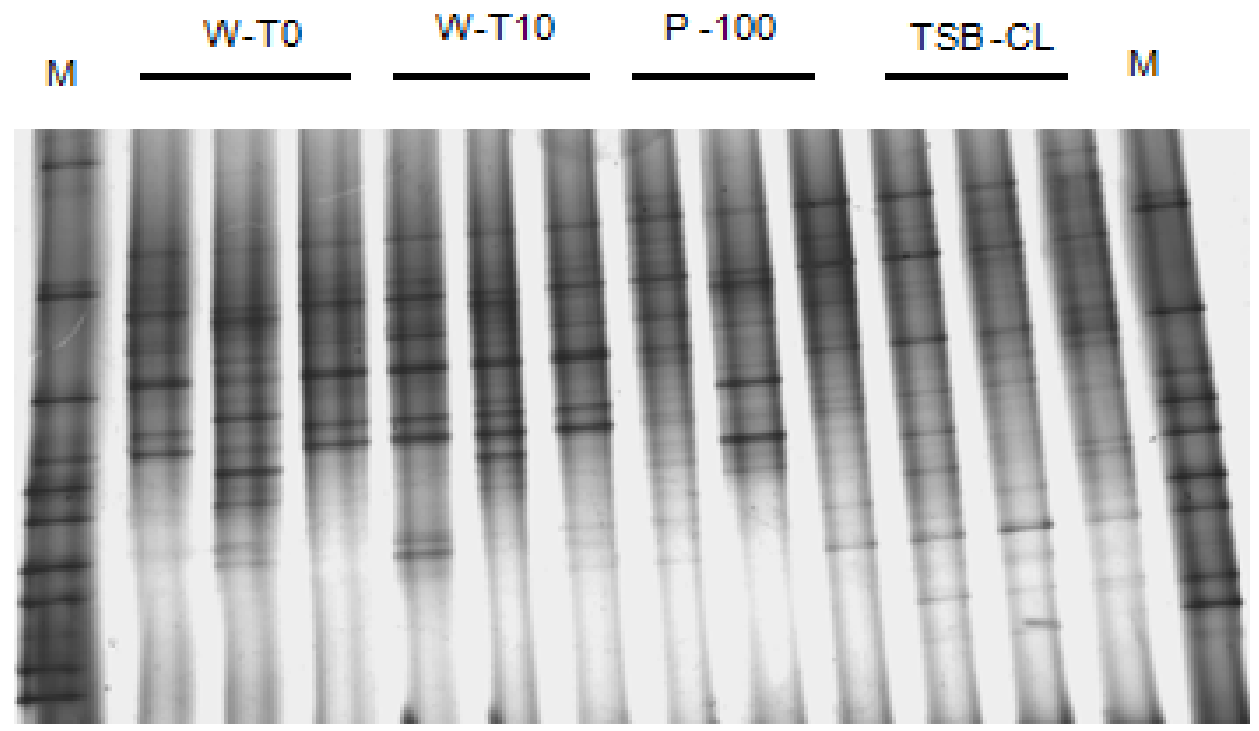

(B) 
Figure 5. Dendrogram generated from the pattern of bands obtained by DGGE (Figure 3). (A) AS-1 and (B) VP-1. Cluster analysis was performed using the PRIMER v5 software [43]. The binary matrix was transformed into a similarity matrix using the Bray Curtis measure. W- $\mathrm{T}_{0}$-water samples at time zero; W- $\mathrm{T}_{10}$-water samples incubated during $10 \mathrm{~h}$ without phages; P-100 - water samples added of $100 \mu \mathrm{L}$ of AS-1 (A) and VP-1 (B) phages and incubated during $10 \mathrm{~h}$; TSB-CL-water samples incubated during $10 \mathrm{~h}$ with TSB and $1 \%$ of chloroform without phages.

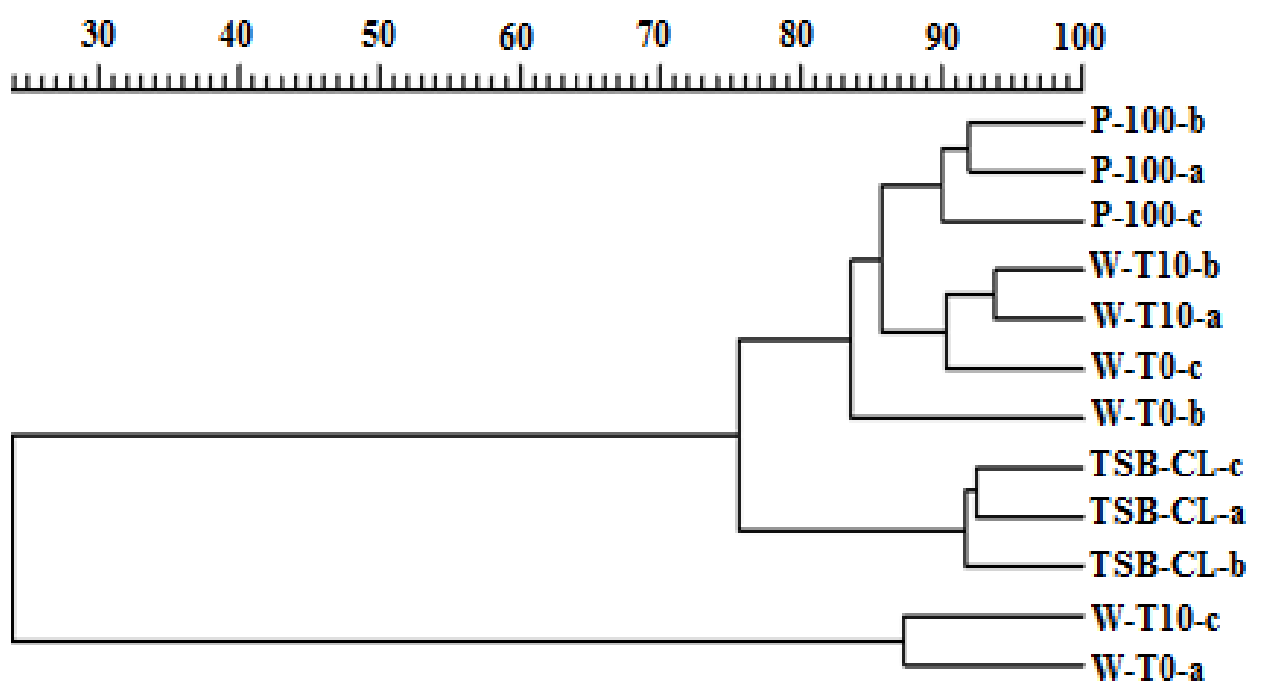

(A)

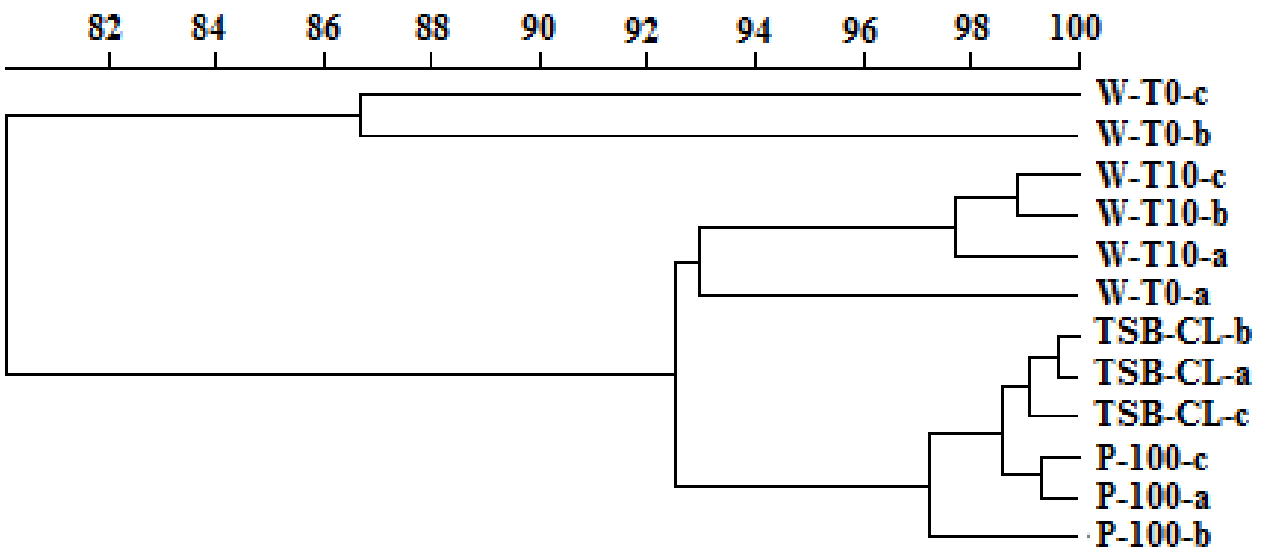

(B)

Cluster analysis of the band patterns obtained from DGGE analysis of the experiment with AS-1 phage revealed the occurrence of two groups (Figure 4A). One that included water samples with added phages (P-100), non-added water samples incubated during $10 \mathrm{~h}\left(\mathrm{~W}-\mathrm{T}_{10}\right)$ and water samples at time zero $\left(\mathrm{W}-\mathrm{T}_{0}\right)$. The other includes water samples incubated during $10 \mathrm{~h}$ with TSB and chloroform without phages (TSB-CL). Samples $\mathrm{W}-\mathrm{T}_{0}, \mathrm{~W}-\mathrm{T}_{10}$ and P-100 were closely grouped (similarity $>80 \%$ ), but were separated from (TSB-CL) (similarity 75\%).

Cluster analysis of the band patterns obtained from DGGE analysis of the experiment with VP-1 phage (Figure 4B) revealed the occurrence of two main groups. One including water samples with added phages (P-100), non-added water samples incubated during $10 \mathrm{~h}\left(\mathrm{~W}-\mathrm{T}_{10}\right)$ and water samples 
incubated during $10 \mathrm{~h}$ with TSB and chloroform (TSB-CL) with a similarity $>92 \%$. The other includes water samples at time zero $\left(\mathrm{W}-\mathrm{T}_{0}\right)$ with a similarity $>86 \%$.

Analysis of similarities (ANOSIM) suggested moderated separation of bacterial communities treated with both tested phages (P100 vs. TSB-CL) (Table 2). However, the addition of TSB and 1\% of chloroform without phages (TSB-Cl) to the microcosm samples and incubation time also resulted in significant separation of the communities.

Table 2. ANOSIM pairwise comparison of DGGE fingerprints of $16 \mathrm{~S}$ rRNA gene fragments after AS-1 (A) and VP-1 (B) phages addition to the microcosms. W- $\mathrm{T}_{0}-$ water samples at time zero; $\mathrm{W}-\mathrm{T}_{10}$-water samples incubated during $10 \mathrm{~h}$ without phages; P-100 - water samples added of $100 \mu \mathrm{L}$ of AS-1 and VP-1 phages and incubated during $10 \mathrm{~h}$; TSB-CL—water samples incubated during $10 \mathrm{~h}$ with TSB and $1 \%$ of chloroform without phages.

\begin{tabular}{ccc}
\hline \multirow{2}{*}{ Groups } & \multicolumn{2}{c}{$\boldsymbol{R}$} \\
\cline { 2 - 3 } & $\mathbf{A S - 1}$ & $\mathbf{V P - 1}$ \\
\hline $\mathrm{WT}_{0}, \mathrm{WT}_{10}$ & 0.037 & 0.333 \\
$\mathrm{WT}_{0}, \mathrm{TSB}-\mathrm{CL}$ & 0.667 & 0.778 \\
$\mathrm{WT}_{0}, \mathrm{P}_{100}$ & 0.333 & 0.556 \\
$\mathrm{TSB}_{1} \mathrm{CL}, \mathrm{P}_{100}$ & 0.630 & 0.519 \\
$\mathrm{TSB}_{10 L}, \mathrm{WT}_{10}$ & 0.963 & 0.407 \\
$\mathrm{P}_{100}, \mathrm{WT}_{10}$ & 0.556 & 0.185 \\
\hline
\end{tabular}

\subsection{Discussion}

Fish infection by pathogenic bacteria is a progressive problem for the development of aquaculture worldwide. Several chemotherapies, such as the utilization of antibiotics, have contributed to a rapid and effective way to treat or prevent bacterial infections. However, the increasing problem of antibiotic resistance in common pathogenic bacteria and the concern about spreading antibiotics in the environment, bring the need of finding new methods to control fish pathogenic bacteria. Therefore, phage therapy represents a potentially viable alternative to antibiotics and to other antimicrobial compounds to inactivate indigenous and non-indigenous pathogenic bacteria in fish farming plants.

In this study, two phages were isolated from water aquaculture system, using isolated bacteria V. parahaemolyticus (phage VP-1) and A. salmonicida (phage AS-1) as hosts. TEM examination of the two presumptive phage isolates, indicated that they are assigned to the order Caudovirales because they display binary symmetry, long tail [42] and double stranded DNA [43].

The success of phage therapy in aquaculture depends mainly on the phages selected to inactivate the fish pathogenic bacteria [13]. The selected phages must remain viable in marine waters, infecting pathogenic bacteria but not altering significantly the non-pathogenic bacteria that have an important ecological role. The results of this study showed that both phages of fish pathogenic bacteria can survive in the aquaculture water at $25^{\circ} \mathrm{C}$ temperature and that after 10 hour incubation they do not alter significantly the structure of the overall bacterial community. Unlike antibiotics, phages are self-replicating as well as self-limiting and, consequently, they replicate exponentially as bacteria replicate and decline when bacterial numbers decrease $[27,44,45]$. In this study it was possible to 
produce phages suspensions with high titers, up to $10^{10} \mathrm{PFU} \mathrm{mL}^{-1}$, suitable to use in phage therapy, that declined when bacteria were removed, but maintaining their high concentrations even after three months in marine water. These facts suggest that VP-1 and AS-1 phages are well adapted to the aquatic environment, surviving for long periods in marine waters and present a low ecological impact on the structure of the natural bacterial community. More extensive studies should be performed to test other incubation times and different phage concentrations on the aquaculture field.

Although it has been described that phages are specific to a single species or even strain of bacteria [46-48], the results of this study show that the VP-1 and AS-1 phages can inactivate pathogenic bacteria from different families with a high efficacy of plating. The phage VP-1 infected $V$. anguillarum and $A$. salmonicida, presenting an efficacy of 83.27 and $64.75 \%$, respectively. The phage AS-1 infected $V$. anguillarum and $V$. parahemolyticus presenting a higher efficacy $95 \%$. Phages of the indigenous bacterium Vibrio, which is responsible for the majority of the outbreaks in fish farms [6,12], infect their host family but also bacteria of other families, such as Aeromonas. Similar results were obtained by Miller et al. who isolated a broad-host-range vibriophage, KVP40, from sea water using $V$. parahaemolyticus (EB101), as the indicator host range of KVP40 extended over at least eight Vibrio sp. and one Photobacterium sp. [49]. Therefore, VP-1 and AS-1 phages can be tested for the ability to reduce the severity of different fish infections, namely Vibrio infections and furunculosis. However, these phages are not suitable to treat photobacteriosis. As the isolated bacteria, namely $V$. parahaemolyticus, display resistance to a broad range of antibiotics and are infected by the two viruses, phage therapy is a potentially viable alternative to antibiotics, inactivating even bacteria resistant to seven different antibiotics [50].

Although the phages VP-1 infect all the tested bacteria, they show only a moderate impact on the overall bacterial community structure. This fact contributes to the ecological balance of the microbial communities inhabiting the water of semi-intensive aquaculture regimes, where part of the fish food results from organic matter transformed and/or produced by aquatic bacteria. The number of ribotypes in water samples added of phages VP-1 after $10 \mathrm{~h}$ of incubation (P-100, Figure 4B) was similar to that obtained for water samples without phages addition after the same period of incubation $\left(\mathrm{W}-\mathrm{T}_{10}\right.$, Figure 4B). The pattern of bands obtained for water samples incubated during the $10 \mathrm{~h}\left(\mathrm{~W}-\mathrm{T}_{0}, \mathrm{P}-100\right.$; TSB-CL) was, however, slightly distinct from those obtained for non-incubated samples $\left(\mathrm{W}-\mathrm{T}_{0}\right.$, Figure 4B) (Bray-Curtis similarity index of 80\%). This difference can be explained by the bottle effect. It is well known that placing samples into containers terminates the exchange of cells, nutrients and metabolites with in situ surrounding environment [51], affecting bacterial community composition. The ANOSIM confirms these results, indicating only a moderate separation of bacterial communities after phage inoculation (P100 vs. TSB-CL, Table 2). The DGGE results for phages AS-1 show also a moderated effect on the structure of bacterial community. The bottle effect for these samples was not as evident as for the samples of $V$. parahaemolyticus. As the addition of both phages show only moderate impact on the dominant members of the total bacterial community structure, it will be interesting to test the effect of adding theses phages simply on specific bacterial groups, namely Aeromonas and Vibrio, using primers specific for these groups in the DGGE approach instead of the universal primers used in this study.

Previous studies in this aquaculture system [52] showed that the bacterial community structure of total and pathogenic bacterial communities varied seasonally, showing a higher complexity during the 
warm season. The authors concluded that: (1) the seasonal variation of the bacterial communities imply the need for a careful monitoring of water throughout the year in order to select suitable phages to inactivate fish pathogenic bacteria; and (2) that the spring season seems to be the critical time period when phage therapy should be applied. Consequently, the impact of the phages on the structure of the bacterial community can also vary seasonally. However, the study of the impact of the phages on the bacterial community was conducted during the warmer seasons which is the critical time period when phage therapy should be applied [52].

Further studies should be performed to select the most effective phage strain or effective combination of phage strains for therapeutic applications. It will be also important to characterize the capacity of phages to reduce their host fitness. Moreover, it should be emphasized that before using bacteriophages for therapy, it would be important to test whether they carry any virulence genes, that is, if there is any potential for lysogenic conversion.

\section{Experimental Section}

\subsection{Study Area and Sampling}

This study was conducted in the semi-intensive aquaculture system Corte das Freiras located in the estuarine system Ria de Aveiro (latitude: $40^{\circ} 37^{\prime} 51.44^{\prime \prime} \mathrm{N}$, longitude $8^{\circ} 40^{\prime} 31.75^{\prime \prime} \mathrm{W}$ ) on the north-western coast of Portugal. Since the aquaculture is located near the city of Aveiro it is subjected to some contamination introduced by human wastes and, therefore subjected to chemotherapy treatment. The aquaculture is divided in ten earthen ponds of approximately $2500 \mathrm{~m}^{2}$ each, which are supplied with water from Ria de Aveiro. The Sparus aurata (gilthead seabream) and Dicentrarchus labrax (European seabass) cultured in this aquaculture system are stocked at 12,000 fish/ha.

Water samples were collected between March 2009 and September 2009, two hours before low tide, in mild weather conditions, from a culture tank of Sparus aurata. Samples from surface water were taken directly into sterile glass bottles and kept cold and in the shade during transport to the laboratory where they were processed within the next $1-2 \mathrm{~h}$.

\subsection{Water Properties}

Temperature and salinity were measured in the field using a WTW LF 196 Conductivity Meter. Dissolved oxygen was also determined in the field with a WTW OXI 96 oxygen meter equipped with a WTW BR 190 stirrer. $\mathrm{pH}$ was measured in the laboratory, at $25{ }^{\circ} \mathrm{C}$, with a $\mathrm{pH}$ probe (Orion, Model 290 A).

\subsection{Microorganisms and Growth Conditions}

The three bacterial strains $V$. anguillarum, $V$. parahaemolyticus and A. salmonicida used in this study were previously isolated in our laboratory from the aquaculture systems Corte das Freiras of Ria de Aveiro (Portugal) [50]. The other nine strains, P. damselae subsp. damselae (ATCC 33539), P. damselae subsp. piscicida (ATCC 29690) [18], E. coli [53], V. fischerie (ATCC 49387), P. aeruginosa, P. fluorescens, P. putida, P. segetis and P. gingeri [54], used in this work were obtained in previous studies. The bacteria were stored at $4{ }^{\circ} \mathrm{C}$ in tryptic soy broth (TSB, Merck). Before each 
assay the strains were grown aerobically for $24 \mathrm{~h}$ at $25^{\circ} \mathrm{C}$ in $30 \mathrm{~mL}$ of TSB. Then, aliquots of these cultures $(300 \mu \mathrm{L})$ were aseptically subcultured to $30 \mathrm{~mL}$ of fresh TSB medium and grew overnight at $25^{\circ} \mathrm{C}$.

\subsection{Bacteriophages Isolation and Purification}

Bacteriophages were isolated from aquaculture water, collected at Corte Freiras (Ria Aveiro, Portugal). Two pathogenic bacteria of fish ( $V$. parahaemolyticus and A. salmonicida) were used as hosts to produce the phage suspensions.

Five hundred milliliters of water was filtered sequentially by $3 \mu \mathrm{m}$ and then $0.22 \mu \mathrm{m}$-pore-size polycarbonate membranes (Poretics). The filtered water was added to five hundred milliliters of TSB with double concentration and one milliliter of the respective bacterial host suspension in exponential growth. Suspensions were incubated overnight at $25^{\circ} \mathrm{C}$, with shaking $\left(100 \mathrm{rpm} \mathrm{min}{ }^{-1}\right)$ and were then centrifuged at $9000 \mathrm{~g}$ for $10 \mathrm{~min}$ (rotor JA.25.50, Beckman Avanti ${ }^{\mathrm{TM}} \mathrm{J}-25 \mathrm{I}$ ). The supernatant was then filtered through $0.22 \mu \mathrm{m}$ pore-size polycarbonate membranes. The spot test method, a procedure based on the double layer plaque technique [55] with minor modifications, was used as an initial test for the presence of phages. Three milliliters of TSB $0.6 \%$ agar (Merck), previously inoculated with $300 \mu \mathrm{L}$ of a specific bacterial culture with $8-10 \mathrm{~h}$ were overlaid on solid tryptone soy agar (TSA, Merck) and spotted with $10 \mu \mathrm{L}$ of the filtered suspension. Petri plates were incubated at $25^{\circ} \mathrm{C}$ for $6-8 \mathrm{~h}$. A clear zone in the plate, resulting from the lysis of host bacterial cells, indicated the presence of phages.

In order to isolate phages from this clear lysis zone, serial dilutions in phosphate buffered saline (137 mmol ${ }^{-1} \mathrm{NaCl}$ (Sigma), $2.7 \mathrm{mmol} \mathrm{L} \mathrm{KCl}$ (Sigma), $8.1 \mathrm{mmol}^{-1} \mathrm{Na}_{2} \mathrm{HPO}_{4} \cdot 2 \mathrm{H}_{2} \mathrm{O}, 1.76 \mathrm{mmol}^{-1}$ $\mathrm{KH}_{2} \mathrm{PO}_{4}$ (Sigma), $\mathrm{pH}$ 7.4) were prepared from the phage stocks obtained above. A colony of the respective host strain was grown $3-4 \mathrm{~h}$ (early-log phase culture) in $5 \mathrm{~mL}$ of TSB. A volume of $500 \mu \mathrm{L}$ of phage-containing sample and $100 \mu \mathrm{L}$ of host culture were mixed with $3 \mathrm{~mL}$ of $0.6 \% \mathrm{TSB}$ agar, overlaid onto TSA plates and incubated at $25{ }^{\circ} \mathrm{C}$ for $6-8 \mathrm{~h}$. Phages were purified by successive single plaque isolation, from the higher dilutions plates where plaques were still distinct. A single plaque was picked from the bacteria lawn, inoculated into an early-log phase host culture, and the lysate plated as described above. After repeating the cycle two more times, lysates from single plaques were treated with $1 \%$ chloroform, mixed and centrifuged at $9000 \mathrm{~g}$ for $5 \mathrm{~min}$. The phages were recovered from the upper phase suspension and filtered through $0.22 \mu \mathrm{m}$ membranes. Phages stocks were stored at $4{ }^{\circ} \mathrm{C}$.

The number of phages present in this suspension was determined using the soft agar overlay technique, according to Adams [56]. Successive dilutions of the phage suspension were performed in a phosphate buffered saline and $500 \mu \mathrm{L}$ of each dilution together with $100 \mu \mathrm{L}$ of the respective bacterial host culture were mixed with $3 \mathrm{~mL}$ of TSB $0.6 \%$ top agar layer and placed over a TSA plate. The plates were incubated at ambient temperature $\left(25^{\circ} \mathrm{C}\right)$ for $6-8 \mathrm{~h}$, the number of plaques was counted and the results expressed as plaque forming units per milliliter $\left(\mathrm{PFU} \mathrm{mL} \mathrm{m}^{-1}\right.$ ). Phage titration was performed in triplicate.

\subsection{Sample Preparation for Transmission Electron Microscopy (TEM)}

Each phage suspension $(10 \mathrm{~mL})$ was centrifuged directly onto formvar-coated carbon-stabilized 400 mesh copper electron microscopy grids as previously described [57]. The viruses were 
ultracentrifuged at $100,000 \mathrm{~g}$ for $1 \mathrm{~h} 30 \mathrm{~min}$ at $25^{\circ} \mathrm{C}$ in a Beckman L8-80K ultracentrifuge equipped with a swing-out rotor (SW28). After centrifugation, the grids were rinsed briefly with distillated water, negatively stained with $1.5 \%(\mathrm{w} / \mathrm{v})$ uranyl acetate for 60 seconds [58] air-dried and examined with a JEOL 100CX transmission electron microscope at a magnification of $100,000 \times$ and an accelerating voltage of $100 \mathrm{kV}$.

\subsection{Concentration of Bacteriophage Particles with PEG for Nucleic Acid Extraction}

Precipitation of bacteriophage particles with polyethylene glycol (PEG) was used as described by Sambrook and Russel [59]. PEG 8000 was added to the centrifuged lysate and gently mixed to dissolve. The lysates were incubated at $4{ }^{\circ} \mathrm{C}$ for $60 \mathrm{~min}$ and the precipitated particles pelleted by spinning at $11,000 \mathrm{~g}$ for $10 \mathrm{~min}$. Pellets were resuspended in TE buffer [10 $\mathrm{mM}$ Tris $\mathrm{HCl}, 1 \mathrm{mM}$ ethylenediamine tetraacetic acid (EDTA), $\mathrm{pH}$ 8.0]. The phage and bacteria debris was extracted with chloroform and the aqueous phase was collected.

\subsection{Nucleic Acid Extraction and Amplification of Phage DNA Using Phi29 DNA Polymerase}

The extraction of nucleic acid from phage particles was conducted as described by Griffiths et al. [60]. Extractions were performed by the addition of $0.5 \mathrm{~mL}$ of hexadecyltrimethylammonium bromide (CTAB) extraction buffer and $0.5 \mathrm{~mL}$ of $0.5 \mathrm{~mL}$ of phenol-chloroform-isoamyl alcohol $(25: 24: 1)$ (pH 8.0) CTAB. Samples were lysed for $30 \mathrm{~s}$ in a FastPrep FP120 (BIO 101/Savant) at a speed of $5.5 \mathrm{~ms}^{-1}$, and the aqueous phase containing nucleic acids was separated by centrifugation $(16,000 \mathrm{~g})$ for $5 \mathrm{~min}$ at $4{ }^{\circ} \mathrm{C}$. The aqueous phase was then extracted and phenol was removed by mixing with an equal volume of chloroform-isoamyl alcohol followed by repeated centrifugation $(16,000 \mathrm{~g})$ for $5 \mathrm{~min}$ at $4{ }^{\circ} \mathrm{C}$. Total nucleic acids were subsequently precipitated from the extracted aqueous layer with 2 volumes of $30 \%(\mathrm{wt} / \mathrm{v})$ polyethelene glycol-1.6 $\mathrm{M} \mathrm{NaCl}$ for $2 \mathrm{~h}$ at room temperature, followed by centrifugation $(18,000 \mathrm{~g})$ at $4{ }^{\circ} \mathrm{C}$ for $10 \mathrm{~min}$. Pelleted nucleic acids were then washed in ice cold $70 \%(\mathrm{v} / \mathrm{v})$ ethanol and air dried prior to resuspension in $50 \mathrm{~mL}$ of TE buffer $(10 \mathrm{mM}$ Tris $\mathrm{HCl}, 1 \mathrm{mM}$ ethylenediamine tetraacetic acid (EDTA), $\mathrm{pH}$ 8.0).

Nucleic acid yield was estimated using NanoDrop ND-1000 spectrophotometer (version 3.3). DNA purification was performed using the Geneclean spin kit (MP Biomedicals, LLC).

The TempliPhi DNA Sequencing Template Amplification kit (Amersham Biosciences) was used as described in the manufacturer protocol booklet with the following exceptions. The template $(2 \mu \mathrm{L})$ was added to a mixture of $6 \mu \mathrm{L}$ of sample buffer and $2 \mu \mathrm{L}$ of dd-water. During the denaturation step, a reaction premix of $12 \mu \mathrm{L}$ reaction buffer $+0.8 \mu \mathrm{L}$ BSA $(0.25 \mu \mathrm{g} / \mu \mathrm{L})+0.5 \mu \mathrm{L}$ enzyme mix, for each sample was prepared. Once tubes were cooled from denaturation temperature, $7 \mu \mathrm{L}$ of this freshly made premix was added to each sample and were incubated at $30{ }^{\circ} \mathrm{C}$ for $4.5 \mathrm{~h}$. The reaction was terminated at $65^{\circ} \mathrm{C}$ for $10 \mathrm{~min}$. Samples were analyzed using $0.8 \%$ agarose gel electrophoresis at $80 \mathrm{~V}$.

\subsection{Nucleic Acid Characterization}

The nucleic acid extracts were digested with DNase I (Ambion), RNase I (Sigma Aldrich), BamI (Fermentas) and PstI (Fermentas) as described by the manufacturer. The reactions were terminated by 
heating at $80{ }^{\circ} \mathrm{C}$ for $5 \mathrm{~min}$. Nucleic acid yield was observed through agarose gel electrophoresis $(0.8 \%$ agarose gel electrophoresis at $80 \mathrm{~V}$ ).

\subsection{Phage Host Range Analysis}

Bacterial susceptibility to bacteriophage was assayed for the five pathogenic bacteria of fish ( $V$. parahaemolyticus, A. salmonicida, $V$. anguillarum, $P$. damselae subsp. damselae and $P$. damselae subsp. piscicida). The spot test method was used as an initial approach for the detection of bacterial infection [55]. The efficiency of plating was determined for the bacteria with positive spot tests (occurrence of lysis plaques) using the soft agar overlay technique [56]. Efficacy of plating for each host was calculated by comparison with an efficacy of $100 \%$ for the $V$. parahaemolyticus and A. salmonicida phages on the A. salmonicida and $V$. parahaemolyticus bacteria, respectively. For each phage three independent experiments were done and the results presented are the average of the three assays.

\subsection{Determination of Phage Survival}

The survival of VP-1 and AS-1 phages was tested in aquaculture marine water collected on July and August 2009. One hundred milliliters of water were filtered through $3 \mu \mathrm{m}$ and then by $0.22 \mu \mathrm{m}$ pore-size membranes (Poretics) and $50 \mu \mathrm{L}$ of phage suspension was added, followed by incubation at $25^{\circ} \mathrm{C}$ with shaking $\left(100 \mathrm{rpm} \cdot \mathrm{min}^{-1}\right)$ in the dark. Phage titer was determined at time zero and at intervals of $72 \mathrm{~h}$, using the soft agar overlay technique [56]. The plates were incubated at ambient temperature $\left(25^{\circ} \mathrm{C}\right)$ for $6-8 \mathrm{~h}$. For each phage three independent experiments were done and the results presented are the average of the three assays. The results are presented by survival curves plotted as logarithmic phages reduction $\left(\log \mathrm{PFU} \cdot \mathrm{mL}^{-1}\right)$ vs. time incubation (in days).

\subsection{Impact of Phage Addition on Bacterial Community Structure}

For each phage, $150 \mathrm{~mL}$ of aquaculture water, collected on June and July 2009, were added to each of 12 erlenmeyers. Each of the phages was added to three erlenmeyer flasks at a final concentration of $4.1 \times 10^{6} \mathrm{PFU} \cdot \mathrm{mL}^{-1}$ for the AS-1 phage and $1.1 \times 10^{7} \mathrm{PFU} \cdot \mathrm{mL}^{-1}$ for the VP-1 phage P-100. Three negative controls were also included $(\mathrm{n}=3$ flasks each) to control for the phage preservative solution (TSB with $1 \%$ chloroform; TSB-CL), a water incubation without added phage $\left(\mathrm{W}-\mathrm{T}_{10}\right)$, and water control without incubation $\left(\mathrm{W}-\mathrm{T}_{0}\right)$. The P-100, TSB-CL and $\mathrm{W}-\mathrm{T}_{10}$ were incubated at $25{ }^{\circ} \mathrm{C}$ during $10 \mathrm{~h}$. After incubation, each sample was filtered through $0.22 \mu \mathrm{m}$ pore-size filters (Poretics). W- $\mathrm{T}_{0}$ samples were not incubated, being immediately filtered.

For the extraction of bacterial DNA, the bacterial cells retained on the membranes were resuspended in $2 \mathrm{~mL}$ of TE buffer $(10 \mathrm{mM}$ Tris $\mathrm{HCl}, 1 \mathrm{mM}$ ethylenediamine tetraacetic acid (EDTA), pH 8.0) and centrifuged. After resuspension in $200 \mathrm{~mL} \mathrm{TE,} 2 \mathrm{mg} \mathrm{mL}^{-1}$ lysozyme solution was added to induce cell lysis and incubated at $37{ }^{\circ} \mathrm{C}$ for $1 \mathrm{~h}$, according to the procedure described by Henriques et al. [61]. DNA was resuspended in TE buffer and stored at $-20{ }^{\circ} \mathrm{C}$.

The DNA extracted was used to amplify 16 rRNA gene fragments, using a nested PCR approach. In the first PCR, the universal bacterial primers $27 \mathrm{~F}$ and $1494 \mathrm{R}$ were used to amplify $c a$. $1450 \mathrm{bp}$ of the 
16S rRNA gene [62]. The reaction was carried in a Multigene Gradient Thermal Cycler from MIDSCI. A reaction mixture of $25 \mu \mathrm{L}$ was prepared containing $1 \times$ PCR buffer (Fermentas), $0.2 \mathrm{mM}$ deoxynucleoside triphosphates, $3.75 \mathrm{mM} \mathrm{MgCl}_{2}, 4 \%$ (v/v) bovine serum albumin (BSA, Sigma), $0.1 \mu \mathrm{M}$ primers synthesized by IBA , $1 \mathrm{U}$ Taq polymerase (Fermentas), and template DNA ( $c a .10 \mathrm{ng}$ ). After 5 min of denaturation at $94{ }^{\circ} \mathrm{C}, 30$ thermal cycles of $45 \mathrm{~s}$ at $94{ }^{\circ} \mathrm{C}, 45 \mathrm{~s}$ at $56{ }^{\circ} \mathrm{C}$, and $1.5 \mathrm{~min}$ at $72{ }^{\circ} \mathrm{C}$ were carried out. A final extension step at $72{ }^{\circ} \mathrm{C}$ for $10 \mathrm{~min}$ was performed to finish the reaction. One microlitres of the product of the first PCR was used as the template for a second PCR with bacterial DGGE primers F968-GC (5'-GC-clamp-AACGCGAAGAACCTTAC-3') and R1401 (5'-GCGTGTGTACAAGACCC-3') [63], according to the procedure described by Pereira et al. [52]. PCR products were checked using standard agarose gel electrophoresis $(0.8 \%$ agarose, $1 \times$ TAE buffer; $100 \mathrm{~V}$ for $40 \mathrm{~min}$ ) and ethidium bromide staining [64].

Samples containing approximately equal amounts of PCR amplicons were analyzed by DGGE, performed with a CBS System (CBS Scientific Company, Del Mar, CA, USA). PCR products were loaded onto 6-9\% polyacrylamide gel in 1 xTAE buffer $\left(20 \mathrm{mmol} \cdot \mathrm{L}^{-1}\right.$ Tris, $10 \mathrm{mmol} \cdot \mathrm{L}^{-1}$ acetate, $0.5 \mathrm{mmol} \cdot \mathrm{L}^{-1}$ EDTA $\mathrm{pH} 7.4$ ). The $6-9 \%$ polyacrylamide gel (bisacrylamide:acrylamide $=37.5: 1$ ) was made with a denaturing gradient ranging from 32 to $60 \%$. Electrophoresis was performed at $60{ }^{\circ} \mathrm{C}$ for $16 \mathrm{~h}$ at $150 \mathrm{~V}$. Following electrophoresis, the gels were silver stained, according to the procedure described by Pereira et al. [52].

The gels were digitalized and analyzed with the software package Gelcompar 4.0 program (Applied Maths) as previously described by Smalla et al. [65]. After automatic band search, the bands detected were carefully checked and artefacts were removed. The sets used for band detection were 5\% minimal profiling (area along the densitometric curve) and $0.5 \%$ minimal area. The positioning and quantification of bands were carried out by setting tolerance and optimization at 5 points, i.e., 1.0\%. The band positions and their corresponding intensities from each treatment were exported to Excel files and the band surface was converted to relative intensity by dividing its surface by the sum of all band surfaces in a lane. Bray-Curtis similarities were calculated based on the band position and intensity. The matrices of similarities were then used for multivariate analyses of DGGE profiles using analysis of similarities (ANOSIM) with the PRIMER 5 software package (Primer-E Ltd., Plymouth, UK). The $R$ value in ANOSIM ranges from 0 to 1 , where $R>0.75$ indicates significant differences, $R>0.5$ moderate separation and $R<0.25$ high similarity [42].

\section{Conclusions}

The results suggest that the bacterial phages tested in this study have long term survival in marine water and show only a moderate impact on the overall bacterial community structure. Moreover, the wide host range of VP-1 and AS-1 improves their potential to inactivate a broader range of fish pathogenic bacteria. Therefore, the phages investigated in this study are potential candidates for development of phage therapy directed to the prophylaxis of disease outbreak and/or treatment of symptomatic diseases in marine aquaculture systems. Further studies should be performed to select the most effective phage strain or effective combination of phage strains for therapeutic applications. Experiments to determine the effectiveness of phage against natural infections should also be performed in order to develop an efficient protocol to treat fish bacterial infections. 


\section{Acknowledgements}

Thanks are due to the University of Aveiro and the Center for Environmental and Marine Studies (CESAM) for funding. C. Pereira was funded by FEDER COMPETE (Competitiveness Factors Operational Programme) and by FCT (Portuguese Fundation for Science and Technology), under the research project FCOMP-01-0124-FEDER-013934. Financial support to Y. J. Silva and A. L. Santos were provided by FCT in the form of a PhD grant (SFRH/BD/65147/2009) and (SFR/BD/40160/2007), respectively. We are also grateful to aquaculture staff for the help with water sampling.

\section{References}

1. FAO. The State of World Fisheries and Aquaculture-2008; FAO (Fisheries and Aquaculture Department): Rome, Italy, 2009.

2. FAO. The State of World Fisheries and Aquaculture; FAO (Fisheries and Aquaculture Department): Rome, Italy, 1998.

3. Flegel, T.W. Detection of major penaeid shrimp viruses in Asia, a historical perspective with emphasis on Thailand. Aquaculture 2006, 258, 1-33.

4. Saksida, S.; Constantine, J.; Karreman, G.A.; Neville, C.; Sweeting, R.; Beamish, R. Evalution of sea lice, Lepeophtheirus salmonis, abundance levels on farmed salmon in British Columbia, Canada. In Proceedings from the International Symposium on Veterinary Epidemiology and Economics XI, Cairns, Australia, August 2006.

5. Subasinghe, R.P.; Bondad-Reantaso, M.G.; McGladdery, S.E. Aquaculture in the Millennium. In Proceedings of the Conference on Aquaculture in the Third Millennium, Bangkok, Thailand, 2001; Subasinghe, R.P., Bueno, P., Phillips, M.J., Hough, C., McGladdery, S.E., Arthur, J.R., Eds.

6. Toranzo, A.E.; Barreiro, S.; Casal, J.F.; Figueras, A.; Magariños, B.; Barja, J.L. Pasteurellosis in cultured gilthead seabream, Sparus aurata: First report in Spain. Aquaculture 1991, 99, 1-15.

7. Benediktsdóttir, E.; Helgason, S.; Sigurjónsdóttir, H. Vibrio spp. isolated from salmonids with shallow skin lesions and reared at low temperature. J. Fish Dis.1998, 21, 19-28.

8. Blanch, A.R.; Alsina, M.; Simón, M.; Jofre, J. Determination of bacteria associated with reared turbot (Scophthalmus maximus) larvae. J. Appl. Microbiol. 1997, 82, 729-734.

9. Eguchi, M.; Fujiwara, E.; Miyamoto, N. Survival of Vibrio anguillarum in freshwater environments: Adaptation or debilitation? J. Infect. Chemother. 2000, 6, 126-129.

10. Hanna, P.J.; Altmann, K.; Chen, D.; Smith, A.; Cosic, S.; Moon, P. Development of monoclonal antibodies for the rapid identification of epizootic Vibrio species. J. Fish Dis. 1991, 15, 63-69.

11. Sung, H.H.; Li, H.C.; Tsai, F.M.; Ting, Y.Y.; Chao, W.L. Canges in the composition of Vibrio communities in pond water during tiger shrimp (Penaeus monodon) cultivation and in the hepatopancreas of healthy and diseased shrimp. J. Exp. Mar. Biol. Ecol. 1999, 239, 261-271.

12. Noya, M.; Magarinos, B.; Lamas, J. Interactions between peritoneal exudate cells (PECs) of gilthead seabream (Sparus aurata) and Pasteurella piscicida. A morphological study. Aquaculture 1995, 131, 11-21. 
13. Bernoth, E.M. Furunculosis: Multidisciplinary Fish Disease Research; Academic Press: Waltham, MA, USA, 1997

14. Almeida, A.; Cunha, A.; Gomes, N.C.M.; Alves, E.; Costa, L.; Faustino, M.A.F. Phage therapy and photodynamic therapy: Low environmental impact approaches to inactivate microorganisms in fish farming plants. Mar. Drugs 2009, 7, 268-313.

15. Arijo, S.; Rico, R.; Chabrillon, M.; Diaz-Rosales, P.; Martínez-Manzanares, E.; Balebona, M.C.; Magariños, B.; Toranzo, A.E.; Moriñigo, M.A. Effectiveness of a divalent vaccine for sole, Solea senegalensis (Kaup), against Vibrio harveyi and Photobacterium damselae subsp. piscicida. J. Fish Dis. 2005, 28, 33-38.

16. Lin, X.; Huang, J.C.; Mitchell, T.G.; Heitman, J. Virulence attributes and hyphal growth of C. neoformans are quantitative traits and the MAT $\alpha$ allele enhances filamentation. PLoS Genet. 2006, 2, e187:1801-e187:1814.

17. Reed, P.A.; Francis-Floyd, R. Vibrio Infections of Fish; Institute of Food and Agricultural Sciences, University of Florida: Gainesville, FL, USA, 1996.

18. Romalde, J. Photobacterium damselae subsp. piscicida: An integrated view of a bacterial fish pathogen. Int. Microbiol. 2002, 1, 3-9.

19. Nakai, T.; Park, S.C. Bacteriophage therapy of infectious diseases in aquaculture. Res. Microbiol. 2002, 153, 13-18.

20. Muroga, K. Viral and bacterial diseases of marine fish and shellfish in Japanese hatcheries. Aquaculture 2001, 202, 23-44.

21. Vadstein, O. The use of immunostimulation in marine larviculture: Possibilities and challenges. Aquaculture 1997, 155, 401-417.

22. Alderman, D.J. Geographical spread of bacterial and fungal diseases of crustaceans. Rev. Sci. Tech. IOE 1996, 15, 603-632.

23. Shao, Z.J. Aquaculture pharmaceuticals and biologicals: Current perspectives and future possibilities. Adv. Drug Deliv. Rev. 2001, 50, 229-243.

24. Wahli, T.; Knuesel, R.; Bernet, D.; Segner, H.; Pugovkin, D.; Burkhardt-Holm, P.; Escher, M.; Schmidt-Posthaus, H. Proliferative kidney disease in Switzerland: Current state of knowledge. J. Fish Dis. 2002, 25, 491-500.

25. Abedon, S.T. Bacteriophage Ecology: Population Growth, Evolution, and Impact of Bacterial Viruses; Cambridge University Press: Cambridge, UK, 2008.

26. Biswas, B.; Adhya, S.; Washart, P.; Paul, B.; Trostel, A.N.; Powell, B.; Carlton, R.; Merril, C.R. Bacteriophage therapy rescues mice bacteremic from a clinical isolate of vancomycin-resistant Enterococcus faecium. Infect. Immun. 2002, 70, 204-210.

27. Matsuzaki, S.; Yasuda, M.; Nishikawa, H.; Kuroda, M.; Ujihara, T.; Shuin, T.; Shen, Y.; Jin, Z.; Fujimoto, S.; Nasimuzzaman, M.A.D.; et al. Experimental protection of mice against lethal Staphylococcus aureus infection by novel bacteriophage phi MR11. J. Infect. Dis. 2003, 187, 613-624.

28. Wills, Q.F.; Kerrigan, C.; Soothill, J.S. Experimental bacteriophage protection against Staphylococcus aureus abscesses in a rabbit model. Antimicrob. Agents Chemother. 2005, 49, $1220-1221$. 
29. Park, S.; Nakai, T. Bacteriophage control of Pseudomonas plecoglossicida infection in ayu Plecoglossus altivelis. Dis. Aquat. Organ. 2003, 53, 33-39.

30. Skurnik, M.; Pajunen, M.; Kiljunen, S. Biotechnological challenges of phage therapy. Biotechnol. Lett. 2007, 29, 995-1003.

31. Imbeault, S.; Parent, S.; Lagace, M.; Uhland, C.F.; Blais, J.F. Using Bacteriophages to prevent furunculosis caused by Aeromonas salmonicida in farmed brook trout. J. Aquat. Anim. Health 2006, 18, 203-214.

32. Karunasagar, I.; Shivu, M.M.; Girisha, S.K.; Krohne, G.; Karunasagar, I. Biocontrol of pathogens in shrimp hatcheries using bacteriophages. Aquaculture 2007, 268, 288-292.

33. Nakai, T.; Sugimoto, R.; Park, K.H.; Matsuoka, S.; Mori, K.; Nishioka, T.; Maruyama, K. Protective effects of bacteriophage an experimental Lactococcus gavieae infection in yellowtail. Dis. Aquat. Organ. 1999, 37, 33-41.

34. Vinod, M.G.; Shivu, M.M.; Umesha, K.R.; Rajeeva, B.C.; Krohne, G.; Karunasagar, I.; Karunasagar, I. Isolation of Vibrio harveyi bacteriophage with a potential for biocontrol of luminous vibriosis in hatchery environments. Aquaculture 2006, 255, 117-124.

35. Suttle, C.A.; Chan, A.M. Dynamics and distribution of cyanophages and their effect on marine Synechococcus spp. Appl. Environ. Microbiol. 1994, 60, 3167-3174.

36. Suttle, C.A.; Chen, F. Mechanisms and rates of decay of marine viruses in seawater. Appl. Environ. Microbiol. 1992, 58, 3721-3729.

37. Cottrell, M.T.; Suttle, C.A. Dynamics of a lytic virus infecting the photosynthetic marine picoflagellate Micromonas pusilla. Limnol. Oceanogr. 1995, 40, 730-739.

38. De Paepe, M.; Taddei, F. Viruses' life history: Towards a mechanistic basis of a trade-off between survival and reproduction among phages. PLoS Biol. 2006, 4, e193:1248-e193:1256.

39. Cho, B.C.; Azam, F. Biogeochemical significance of bacterial biomass in the ocean's euphotic 17 zone. Mar. Ecol. Prog. Ser. 1990, 63, 253-259.

40. Pomeroy, L.R. Status and Future Needs in Protozoan Ecology. In Protozoan and Their Role in Marine Processes, NATO ASI Series G: Ecological 20 Sciences; Reid, P.C., Turley, C.M., Burkhill, P.H., Eds.; Springer-Verlag: Berlin, Heidelberg, Germany, 1991; Volume 25, pp. 475-492.

41. Holmfeldt, K.; Middelboe, M.; Nybroe, O.; Riemann, L. Large variabilities in host strain susceptibility and phage host range govern interactions between lytic marine phages and their Flavobacterium hosts. Appl. Environ. Microbiol. 2007, 73, 6730-6739.

42. Ackermann, H.W. Bacteriophage observations and evolution. Res. Microbiol. 2003, 154, 245-251.

43. Clarke, K.R.; Gorley, R.N. Primer v5: User Manual/Tutorial; PRIMER-E: Plymouth, UK, 2001; p. 9.

44. Hagens, S.; Habel, A.; von Uwe, A.; von Gabain, A.; Blasi, U. Therapy of experimental pseudomonas infections with a nonreplicating genetically modified phage. Antimicrob. Agents Chemother. 2004, 48, 3817-3822.

45. Watanabe, R.; Matsumoto, T.; Sano, G.; Ishii, Y.; Tateda, K.; Sumiyama, Y.; Uchiyama, J.; Sakurai, S.; Matsuzaki, S.; Imai, S.; et al. Efficacy of bacteriophage therapy against gut-derived sepsis caused by Pseudomonas aeruginosa in mice. Antimicrob. Agents Chemother. 2007, 51, $446-452$. 
46. Fuhrman, J.A. Marine viruses and their biogeochemical and ecological effects. Nature 1999, 399, 541-548.

47. Mathur, M.; Vidhani, S.; Mehndiratta, P. Bateriophage therapy: An alternative to conventional antibiotics. J. Assoc. Physicians India 2003, 51, 593-596.

48. Thingstad, T.F. Elements of a theory for the mechanisms controlling abundance, diversity, and biogeochemical role of lytic bacterial viruses in aquatic systems. Limnol Oceanogr. 2000, 45, $1320-1328$.

49. Miller, E.S.; Heidelberg, J.F.; Eisen, J.A.; Nelson, W.C.; Durkin, A.S.; Ciecko, A.; Feldblyum, T.V.; White, O.; Paulsen, I.T.; Nierman, W.C.; et al. Complete genome sequence of the broad-hostrange vibriophage KVP40: Comparative genomics of a t4-related Bacteriophage. J. Bacteriol. 2003, 17, 5220-5233.

50. Pereira, C. Use of Bacteriophages on the Inactivation of Pathogenic Bacteria in Aquaculture System; University of Aveiro: Aveiro, Portugal, 2009.

51. Fogg, G.E.; Calvario-Martinez, O. Effects of bottle size in determinations of primary productivity by phytoplankton. Hydrobiologia 1989, 173, 89-94.

52. Pereira, C.; Salvador, S.; Arrojado, C.; Silva, Y.; Santos, A.L.; Cunha, A.; Gomes, N.C.M.; Almeida, A. Evaluating seasonal dynamics of bacterial communities in marine fish aquaculture: A preliminary study before applying phage therapy. J. Environ. Monit. 2011, 13, 1053-1058.

53. Costa, L.; Alves, E.; Carvalho, C.; Tomé, J.; Faustino, M.; Neves, M.; Tomé, A.; Cavaleiro, J.; Cunha, Â.; Almeida, A. Sewage bacteriophage photoinactivation by cationic porphyrins: A study of charge effect. Photochem. Photobiol. Sci. 2008, 7, 415-422.

54. Louvado, A. Isolamento e Caracterização de Bactérias Resistentes a Surfactantes; University of Aveiro: Aveiro, Portugal, 2010.

55. Carey-Smith, G.V.; Billington, C.; Cornelius, A.J.; Hudson, J.A.; Heinemann, J.A. Isolation and characterization of bacteriophages infecting Salmonella spp. FEMS Microbiol. Lett. 2006, 258, 182-186.

56. Adams, N.A. Bacteriophages; John Wiley and Sons Inc.: New York, NY, USA, 1959.

57. Almeida, M.A.; Cunha, M.A.; Alcântara, F. Loss of estuarine bacteria by viral infection and predation in microcosm conditions. Microb. Ecol. 2001, 42, 562-571.

58. Bratbak, G.; Heldal, M. Total Counts of Viruses in Aquatic Environments. In Aquatic Microbial Ecology; Kemp, P.F., Sherr, B.F., Sherr, E.B., Cole, J.J., Eds.; Handbook of Methods in Lewis Publishers: New York, NY, USA, 1993; pp. 135-138.

59. Sambrook, J.; Russell, D.W. Molecular Cloning: A Laboratory Manual, 3rd ed.; Cold Spring Harbor Laboratory Press: New York, NY, USA, 2001.

60. Griffiths, R.I.; Whiteley, A.S.; O’Donnell, A.G.; Bailey, M.J. Rapid Method for Coextraction of DNA and RNA from natural environments for analysis of ribosomal DNA and rRNA-based microbial community composition. Appl. Environ. Microbiol. 2000, 66, 5488-5491.

61. Henriques, I.S.; Almeida, A.; Cunha, A.; Correia, A. Molecular sequence analysis of prokariotic diversity in the middle and outer sections of the Portuguese estuary Ria de Aveiro. FEMS Microbiol. Ecol. 2004, 49, 269-279.

62. Weisburg, W.G.; Barns, S.M.; Pelletier, D.A.; Lane, D.J. 16S ribosomal DNA amplification for phylogenetic study. J. Bacteriol. 1991, 173, 697-703. 
63. Nubel, U.; Engelen, B.; Felske, A.; Snaidr, J.; Wieshuber, A.; Amann, R.I.; Ludwig, W.; Backhaus, H. Sequence heterogeneities of genes encoding 16S rRNAs in Paenibacillus polymyxa detected by temperature gradient gel electrophoresis. J. Bacteriol. 1996, 178, 5636-5643.

64. Sambrook, J.; Fritsch, E.F.; Maniatis, T. Molecular Cloning: A Laboratory Manual; Cold Spring Harbor Laboratory Press: New York, NY, USA, 1989.

65. Smalla, K.; Wieland, G.; Buchner, A.; Zock, A.; Parzy, J.; Kaiser, S.; Roskot, N.; Heuer, H.; Berg, G. Bulk and rhizosphere soil bacterial communities studied by denaturing gradient gel electrophoresis: Plant-dependent enrichment and seasonal shifts revealed. Appl. Environ. Microb. 2001, 67, 4742-4751.

Samples Availability: Available from the authors.

(C) 2011 by the authors; licensee MDPI, Basel, Switzerland. This article is an open access article distributed under the terms and conditions of the Creative Commons Attribution license (http://creativecommons.org/licenses/by/3.0/). 